\title{
Health related quality of life in children with migraine. A controlled study
}

\author{
Saúde e qualidade de vida em crianças com migrânea. \\ Estudo controlado
}

\author{
Mateus Lage Martins', Rafael Corrêa Valério', Tales José Corrêa de Almeida', Vitor Rodrigues Laender', \\ Dilermando Fazito de Resende2, Mauro Eduardo Jurno ${ }^{3,4}$, Pedro Ferreira Moreira Filho ${ }^{4}$ \\ ${ }^{1}$ Medical Students, School of Medicine at Barbacena, MG, Brazil; 2 Professor of Statistics, School of Medicine \\ at Barbacena, MG, Brazil; ${ }^{3}$ Professor and Preceptor, Internal Medicine Residency, School of Medicine at \\ Barbacena, MG, Professor of Post-Graduation, Universidade Federal Fluminense, Rio de Janeiro, RJ, Brazil \\ ${ }^{4}$ Professor of Post-Graduation, Universidade Federal Fluminense, Rio de Janeiro, RJ, Brazil \\ Martins ML, Valério RC, Almeida TJ, Laender VR, Resende DF, Jurno ME, Moreira Filho PF. \\ Health related quality of life in children with migraine. A controlled study. \\ Headache Medicine. 2013;4(2):54-8
}

\section{ABSTRACT}

Background: Headaches are prevalent in the pediatric population. Migraine significantly impacts the health-related quality of life (HRQoL) of sufferers. Objective: To measure the impact of migraine on the HRQoL of children, by applying the Brazilian version of the SF-36 in children with migraine and in controls. Methods: In this cross-sectional study, HRQoL was measured with the SF-36, and scores for the 8 domains of the test were contrasted comparing children (5 to 14 years) with and without migraine. Results: Sample consisted of 66 children (30 with migraine and 36 controls). Mean age was 10.9 years for migraine (Standard Deviation - $\mathrm{SD}=3$ years) and 10.4 for controls (SD $=3.1$ years). Proportion of children with low HRQoL scores was significantly higher in the migraine group, relative to controls, for the 8 domains of the test: vitality, physical functioning, bodily pain, general health perceptions, physical role functioning, emotional role functioning, social role functioning, and mental health. Conclusion: Children with migraine are significantly impacted in their HRQoL, relative to children without migraine.

Keywords: Migraine; Migraine at childhood; Quality of life; Short form 36; Brazilian SF-36

\section{RESUMO}

Introdução: As dores de cabeça são prevalentes na população pediátrica. A migrânea afeta significativamente a qualidade de saúde de vida (QV) dos doentes pediátricos. Objetivo: Avaliar o impacto da migrânea sobre a qualidade de vida (QV) de crianças, através da aplicação da versão brasileira do SF-36 em crianças migranosas e nos controles sadios. Métodos: Estudo transversal, onde a QVRS foi medida através do SF-36, e a pontuação para os oito domínios do teste foram contrastadas comparando-se crianças (5-14 anos) com e sem migrânea. Resultados: A amostra foi composta por 66 crianças $(30$ com migrânea e 36 controles). A média de idade foi de 10,9 anos para migrânea (Desvio Padrão - DP \pm 3 anos) e 10,4 para os controles (DP $\pm 3,1$ anos). Proporção de crianças com baixos índices de QV foi significativamente maior no grupo de enxaqueca, em relação aos controles, para os oito domínios do teste: capacidade funcional, aspectos físicos, dor, vitalidade, aspectos emocionais, saúde mental, estado geral de saúde mental, e mais uma questão de avaliação comparativa de condições atual e de anos atrás. Conclusão: As crianças com enxaqueca são significativamente afetadas em sua $Q V$, em relação às crianças sem enxaqueca.

Palavras-chave: Migrânea; Migrânea na infância; Qualidade de vida; SF-36 versão brasileira 


\section{INTRODUCTION}

Migraines represent an important public health problem, burdening the individual sufferers, their families, and the society. Costs associated with migraine are significative as well, as it is the impact of the disease on health-related quality of life (HRQoL) of the affected sufferers. ${ }^{(1,2)}$

Migraine is prevalent at all ages, including among children and adolescents, being indeed the most common primary headaches in the pediatric population. ${ }^{(2,3)}$ Age directly influences the prevalence of migraine and its gender distribution. In adolescents and young adults, the prevalence is higher in women. Before menarche, prevalence is higher in boys than in girls. ${ }^{(4)}$

Migraine at childhood is associated with impact on the HRQoL at several domains, including social, psychological and physical. It also impacts performance at school, by being associated with absenteeism, early dismissals, and missing physical or recreational activities. Furthermore, pediatric migraine affects interpersonal and family relationships. ${ }^{(5)}$ It has been suggested that children with migraine are sometimes as burdened as those with arthritis or cancer. ${ }^{(6)}$

The burden of migraine is complicated and modified by its comorbidities. It has been reported that children with headaches have levels of stress, fatigue and somatic symptoms that are significantly different than of those without headaches. They are also less likely to report themselves as being happy and seem to have an overall $10 \%$ decrease in their quality of life, relative to controls. ${ }^{(7)}$

Although the impact of migraine on the HRQoL is well described for the adult population, important data gaps exist for the pediatric population. Accordingly, the aim of this study was to define the impact of migraine on the HRQoL of children from 5 to 15 years, by applying the Brazilian version of the SF-36 in children with migraine and in controls. We found the topic of relevance, since it provides an estimate of the impact of the disease from the perspective of the affected sufferer, instead of their parents or providers.

\section{METHODS}

This was a cross-sectional study, comparing two groups of children from 5 to 14 years, with migraine with or without aura $(n=30)$, and without headaches (control group $-\mathrm{n}=36$ ).
Children with migraine were diagnosed by a headache specialist as per the Second Edition of the International Classification of Headache Disorders. ${ }^{(8)}$ They were selected among those registered at the neurology service of the City Public Health Service (DEMASP).

Controls consisted of volunteers without headache, selected among healthy children that were accompanying their parents who were, in turn, patients at the same clinic. All parents consented for their children to participate.

After consultation and agreeing to participate, all children responded to the Brazilian SF-36, a validated version of the Medical Outcome Study 36.(9) This questionnaire assesses self-perception of health in its most representative domains. ${ }^{(10)}$ It is a non-disease specific selfapplied questionnaire ${ }^{(10)}$ consisting of closed questions clustered among 8 sections: vitality, physical functioning, bodily pain, general health perceptions, physical role functioning, emotional role functioning, social role functioning, and mental health. For each section, scores range from 0 to $100 .(9,11)$ Based on the scores, the following categories were defined: impaired quality of life (0-60 points) and not impaired (61-100).

The questionnaire was responded by the children, who could consult their parents if difficult in comprehension was evident. For children younger than seven, the questionnaire was responded by the parents or guardians. ${ }^{(2,12)}$

Data were analyzed using Stata 10 (Stata Corp., College Station, Texas). Summary tables and descriptive statistics (mean, standard deviation and proportions) were calculated for each variable. For proportions, contingency tables or ANOVA tables were developed, and the Chi-squared $\left(\chi^{2}\right)$, Fischer Test and Fischer for ANOVA comparisons were used. Multivariate analyses (multinomial logistic regression) adjusted for age and gender. Significance level was defined at the $5 \%$ level.

The study was approved the Ethics in Research Committee of Universidade Presidente Antônio Carlos (UNIPAC) (approval number 827/2010).

\section{RESULTS}

As mentioned, the migraine group consisted of 30 children (63.3\% girls), contrasted with 36 controls (44.5\% girls, $\left.\mathrm{Chi}^{2}(2)=2.3440, \mathrm{p}=0.126\right)$. A total of 13 children with migraine had age from 5 to 10 year (43.3\%), while 17 were from 11 to 15 (56.7\%). In the control group, $50 \%$ of the children were in each age range. No significant 
differences were seen when comparing the age categories between groups $\left(\mathrm{Chi}^{2}(1)=0.2920, \mathrm{P}=0.589\right)$. Mean age was 10.9 years in the migraine group (SD $=3$ ) and 10.4 among controls (SD $=3.1)$. Differences were not significant $(F=0.45, p=0.5044)$.

Table 1 displays the frequency of participants that were impaired in their HRQoL or each of the 8 components of the SF-36, with respective results of the Fisher exact test or Chi-squared test. Proportion of children with low HRQoL scores was significantly higher in the migraine group, relative to controls, for the eight domains of the test: vitality, physical functioning, bodily pain, general health perceptions, physical role functioning, emotional role functioning, social role functioning, and mental health.

Table 1. Health-related quality of life, as measured by the SF-36, as a function of migraine status

\begin{tabular}{|c|c|c|c|c|c|c|}
\hline \multirow[t]{2}{*}{ SF-36 Scale } & \multicolumn{2}{|c|}{ Control } & \multicolumn{2}{|c|}{ Migraine } & \multirow[t]{2}{*}{$\mathrm{Chi}^{2} / \mathrm{F}\left(^{*}\right)$} & \multirow[t]{2}{*}{$\mathrm{p}$ value } \\
\hline & $N$ & $\%$ & $\mathrm{~N}$ & $\%$ & & \\
\hline \multicolumn{7}{|c|}{ Functional capacity } \\
\hline $000-060$ & 0 & 0.0 & 10 & 33.3 & - & $<0.001$ \\
\hline $061-100$ & 36 & 100.0 & 20 & 66.7 & & \\
\hline \multicolumn{7}{|c|}{ Physical functioning } \\
\hline $000-060$ & 1 & 2.8 & 20 & 66.7 & 30.79 & $<0.001$ \\
\hline $061-100$ & 35 & 97.2 & 10 & 33.3 & & \\
\hline \multicolumn{7}{|l|}{ Pain } \\
\hline $000-060$ & 1 & 2.8 & 16 & 53.3 & 21.88 & $<0.001$ \\
\hline $061-100$ & 35 & 97.2 & 14 & 46.7 & & \\
\hline \multicolumn{7}{|l|}{ General health } \\
\hline $000-060$ & 2 & 5.6 & 11 & 36.7 & 10.01 & 0.002 \\
\hline $061-100$ & 34 & 94.4 & 19 & 63.3 & & \\
\hline \multicolumn{7}{|l|}{ Vitality } \\
\hline $000-060$ & 2 & 5.6 & 13 & 43.3 & 13.29 & $<0.001$ \\
\hline $061-100$ & 34 & 94.4 & 17 & 56.7 & & \\
\hline \multicolumn{7}{|l|}{ Social aspects } \\
\hline $000-060$ & 1 & 2.8 & 11 & 36.7 & 12.63 & $<0.001$ \\
\hline $061-100$ & 35 & 97.2 & 19 & 63.3 & & \\
\hline \multicolumn{7}{|c|}{ Emotional aspects } \\
\hline $000-060$ & 4 & 11.1 & 13 & 43.3 & 8.88 & 0.003 \\
\hline $061-100$ & 32 & 88.9 & 17 & 56.7 & & \\
\hline \multicolumn{7}{|l|}{ Mental health } \\
\hline $000-060$ & 1 & 2.8 & 13 & 43.3 & 16.10 & $<0.001$ \\
\hline $061-100$ & 35 & 97.2 & 17 & 56.7 & & \\
\hline
\end{tabular}

\section{DISCUSSION}

Herein we contrasted the HRQoL of children as a function of migraine status. Groups did not differ significantly as a function of age and gender, although girls were numerically over-represented in the migraine group. Children with migraine were slightly older as well. Findings are discussed in the context of each category of the SF-36.

\section{Functional capacity}

While nearly one third of the children with migraine had low scores on this domain, the same was not seen in the control group $(p<0.001)$, suggesting the impact of migraine. For the studied age, this impact is probably reflected in school performance (although absenteeism was not assessed by us), either directly driven by migraine or due to conditions comorbid to migraine. ${ }^{(12)}$ In a study conducted in Austria, children with migraine lost an average of 9 school days per year, while in Italy, absenteeism could be as high as 17 days in 3 months. ${ }^{(13,14)}$

\section{Physical functioning}

Nearly $70 \%$ of the children with migraine had low scores in this domain, relative to $2.8 \%$ in those with control, demonstrating the impact of migraine on physical functioning. Previous studies suggest that nearly $80 \%$ of the children with migraine have symptoms that are important enough to interfere in their ability to play sports or games, which, per se, impacts the HRQoL at this age. ${ }^{(15)}$ Furthermore, children with migraine are more likely than those without migraine of reporting fatigue and tiredness. ${ }^{(2)}$

\section{Pain}

While the vast majority of controls (97\%) had high scores on this domain, less than half of those with migraine had it ( $p<0.001)$, suggesting that children with migraine have other types of pain more frequently than controls. Several of migraine comorbidities cause pain, and children with migraine also seem more likely to be diagnosed with conditions such as ear infections or gastric problems, which also cause pain. ${ }^{(13)}$

\section{General health perception}

Children with migraine were significantly more likely to have low scores in this domain relative to controls (36.7\% vs. $5.6 \%, p<0.002)$ a finding supported by previous reports. In a study conducted in Italy, children with headaches had psychological, physical and social impairments, and higher levels of stress and somatic 
symptoms, relative to controls. ${ }^{(16)}$ Of interest is that children with migraine indeed detect that their health is negatively affected when fulfilling the SF-36, relative to children without migraine.

\section{Vitality}

As for the other categories, important differences were seen between groups (low scores in $43.3 \%$ vs. $5.6 \%$, $\mathrm{p}<0.001)$. In a study conducted in India, $58 \%$ of children with migraine had low scores in this domain, affecting their daily activities, ${ }^{(15)}$ and confirming the impact of migraine on vitality.

\section{Social aspects}

While $97.2 \%$ of controls had high score in this domain, the same happened in $63.3 \%$ of children with migraine $(p<0.001)$, meaning that over one third of children with migraine are socially impacted, a fact that has been previously reported. Children with headaches are nearly three times more likely to have emotional symptoms and behavioral problems that impact their relationships within family, at school, while playing, and overall. (17) Due to their headaches, children with migraine may avoid certain activities that are common for the age and are relevant to group playing.

\section{Emotional aspects}

Once more, differences were significant when comparing children negatively affected in this domain (43.3\% vs $11.1 \%, p=0.003)$. Several studies suggest that children with migraine are more likely to report symptoms of anxiety and depression, relative to children without headaches. ${ }^{(2)}$ Vulnerability, defined as the personality trait that predisposes to anxiety and depression, also contribute to HRQoL impact. ${ }^{(17)}$ It has also been reported that excessive concerning and even catastrophism is more likely in those with migraine, negatively affecting their emotional health. ${ }^{(2)}$

\section{Mental health}

Only $2.8 \%$ of the control children had low scores in this domain, relative to $43.3 \%$ in those with migraine ( $p<0.001$ ). Of all HRQoL domains, psychological functioning is likely the best investigated, often with the use of disease-specific questionnaires for depression and anxiety. These studies confirm the high prevalence of anxiety and depression symptoms in children with migraine. (2) Stress, mainly at school, also influences the relationship between migraine and HRQoL, and dissatisfaction with life was higher in migraineurs with high levels of stress, relative to migraineurs without increased stress. ${ }^{(18)}$

\section{CONCLUSIONS}

Migraine impacts $H R Q \circ L$ in all of the domains measured by the SF-36. Limitations of this study include the relatively small sample size, although we emphasize that all comparisons were significant. Since the study was conducted in a general neurology clinic (not pediatric neurology), available cases were indeed limited. Nonetheless, our study adds to the field, since few studies on the topic of HRQoL in children with migraine have been conducted. Our findings suggest that therapeutic interventions aiming not only to improve migraine, but also to improve HRQoL of affected children are of importance.

\section{REFERENCES}

1. Galdino GS, Albuquerque TLP, Medeiros JLA. Cefaléias primárias: abordagem diagnóstica por médicos não neurologistas. Arq. Neuropsiquiatria. 2007;65(3-A):681-84.

2. Arruda MA, Albuquerque RCAP, Bigal ME. Migrânea na infância e adolescência: avanços que contribuem para a prática clínica. Pediatria Moderna. 2010 Maio/Jun; 46(3):87-100.

3. Bruijn J, Arts WF, Duivenvoorden H, Dijkstra N, Raat H, Passchier J. Quality of life in children with primary headache in a general hospital. Cephalalgia 2009;29(6):624-30.

4. Jacobs H, Gladstein J. Pediatric Headache: A Clinical Review. Headache. 2012 Feb;52(2):333-9.

5. Ferracini GN, Barbosa JS, Speciali JG. Instrumentos para avaliação de qualidade de vida relacionada à saúde em crianças com migrânea. Rev Dor. 2010;1 1 (2):154-60

6. Powers SW, Patton SR, Hommel KA, Hershey AD. Quality of life in childhood migraines: clinical impact and comparison to other chronic illnesses. Pediatrics. 2003 Jul; 1 12(1 Pt 1):e 1-5

7. Langeveld JH, Koot HM, Loonen MC, Hazebroek-Kampschreur AA, Passchier J. A quality of life instrument for adolescents with chronic headache. Cephalalgia. 1996 May; 16(3):183-96.

8. Subcomitê de Classificação das Cefaléias. Classificação Internacional das Cefaléias. $2^{a}$ ed. São Paulo: Alaúde Editorial; 2004.

9. Ciconelli RM. Tradução para o português e validação do questionário genérico de avaliação de qualidade de vida SF-36 (Brasil SF-36). [Tese de Doutorado]. São Paulo: Escola Paulista de Medicina de São Paulo da Universidade Federal de São Paulo; 1999. 
10. Martinez MC. As relações entre a satisfação com aspectos psicossociais no trabalho e a saúde do trabalhador. [Dissertação de Mestrado]. São Paulo: Programa de Pós-Graduação do Departamento de Saúde Ambiental da Faculdade de Saúde Pública da Universidade de São Paulo; 2002.

11. Bacheschi LA, Fortini I. Cefaléias. In: Nitrini R, Bacheschi. A neurologia que todo médico deve saber. $2^{a}$ ed. São Paulo: Athenev; 2003. p. 283-96.

12. Cambier, J, Masson, M, Dehen, H. Neurologia. $11^{a}$ ed. Rio de Janeiro: Guanabara Koogan; 2005. Cefaléias e Algias Faciais; p. 116-26.

13. Lateef TM, Merikangas KR, He J, et al. Headache in a national sample of American children: prevalence and comorbidity. J Child Neurol. 2009;24(5):536-43.

14.Karwautz A, Wöber C, Lang T, Böck A, Wagner-Ennsgraber C, Vesely $C$, et al. Psychosocial factors in children and adolescents with migraine and tension-type headache: a controlled study and review of the literature. Cephalalgia. 1999;19(1):32-43.

15. D'Amico D, Grazzi L, Usai S, et al. Use of the Migraine Disability Assessment Questionnaire in children and adolescents with headache: an Italian pilot study. Headache. 2003;43(7):767-73.

16. Shivpuri D, Rajesh MS, Jain D. Prevalence and characteristics of migraine among adolescents: A questionnaire survey. Indian Pediatr. 2003;40(7):665-9

17. Nodari E, Battistella PA, Naccarella C, Vidi M. Quality of life in young Italian patients with primary headache. Headache. 2002;42(4):268-74

18. Langeveld JH, Koot HM, Passchier J. Do experienced stress and trait negative affectivity moderate the relationship between headache and quality of life in adolescents? Journal of Pediatric Psychology. 1999; 24(1):1-11.

Correspondence

Mauro Eduardo Jurno Rua Fernando Laguardia, 45 - Santa Tereza II 36201-118-Barbacena, MG, Brazil jurno@uol.com.br 